\title{
Non-native English teachers' views on the use of music and songs in teaching English as a foreign language to primary school learners
}

\section{Teuta Agaj Avdiu*}

Corresponding Author: Assist. Prof. Dr., Public University “Kadri Zeka “, Gjilan, Kosovo. ORCID ID: 0000-0003-1992-5946 e-Mail: teuta.agaj@uni-gjilan.net

DOI 10.12975/rastmd.20219310 Submitted 22 October, 2021 Accepted December 17, 2021

\section{Abstract}

Teaching English to children through music has gained considerable attention. The use of songs in the English language classroom has become a subject that has increasingly drawn more interests. This is because songs have many values of language. Songs could be particularly effective for supporting foreign language teaching. Implementing educational songs in teaching English to young learners can develop students' pronunciation, vocabulary and grammar. This study illustrates the situation of teaching English through songs in the time of Covid-19 pandemic in primary schools of Kosovo. The aim of this article is to examine current English teachers' views and perspectives towards the use of music and songs in the language classroom. The instrument used to obtain data is an interview for primary school teachers who teach English in different cities of Kosovo. Five teachers were interviewed to better understand their thoughts towards music utilization into their language classrooms. Questions were mainly designed to elicit attitudes of participants related to the research questions. The results of the study indicate that English teachers have positive attitudes toward the use of music in language teaching and view songs as a significant didactic tool that should be employed in EFL classes. Regarding the utilization of music and songs in the context of Covid 19 pandemic, teachers did not face any difficulties during online learning, on the contrary the music activities kept the enthusiasm alive and made learning interesting and fun. However, during face-to-face learning, the pandemic has affected the employment of songs in the English language classes as the students have to use hand sanitizers all the time and wear masks while singing songs. Teachers have also restricted the movement and group work which might have sought the touching of hands with one another and so on.

\section{Keywords}

Music, Songs, foreign language, English teaching, Young Learners (YLs). 


\section{Introduction}

Music and songs are part of all of our lives. There is music in every human culture. You can hear music almost everywhere today: when listening to the radio, watching TV as well as on various family gatherings, such as birthday celebrations, marriage ceremonies, in restaurants, shops, vehicles, and even on the street (McDermott \& Hauser, 2005).

People can listen to music anytime and anywhere. They also talk about it quite often as music seems to be a very favorite topic especially among teenagers who share their thoughts on the latest news regarding artists or new music videos they have seen recently. It is thought that the use of songs and music is useful to create a social environment, to form a feeling of partnership or just dance (Murphey, 1992).

Songs have various functions. However, this study analyzes music respectively song from the point of view of its use in the educational process. More specifically, this article discusses the utilization of songs as a tool for teaching Albanian students English by a non-native English-speaking teacher. In addition, this study investigates the views of Albanian primary school EFL teachers about music activities and using songs in teaching English to young learners in the context of the COVID-19 pandemic.

\section{Literature review}

Teachers have always had positive attitudes on incorporating music in foreign language classes. In their opinion, music can be of benefit for acquiring foreign languages, for language abilities likewise for motivational or cultural aspects. They also believe that it creates a good, pleasant, relaxing atmosphere and that it reduces stress levels or emotional filters (Engh, 2013a; Tse, 2015).

Musical and language processing exist in the same part of the brain and there seem to be parallels in how musical and linguistic syntax is processed according to the neuroscientists' findings (Maess et al., 2001). There might be some link between language and music. They both share similar elements and concepts such as the prosody which means the study of pitch, duration, and stress that are related to spoken language, and are correlated to music as well (Pearl, 1995). Tone, stress, pauses, timbre, and rhythm are some of the language aspects that music also shares (Stansell, 2005).

Music and language work well together. Historically, we can recall storytelling and song being used as an interchange, as amusement and even as job aids (Edden, 1998).

The employment of songs is the most usual way of incorporating music into the foreign language classroom. A song is defined as a work of art intended to be sung with or without instrumental support (Ratnasari, 2007). Songs are very practical tools to teach students a foreign tongue. They are also essential for primary school learners in foreign language classrooms (Cameron, 2001) and teachers of young learners can contribute to children's early language education by including songs in their lessons (Johnstone, 2002). 
Songs have the ability to alter the monotonous mood in the class and with the calming effect of music, they provide a comfortable learning setting so that students can more easily develop their linguistic skills (Lo \& Li, 1998). Culture, vocabulary, listening, grammar and a host of other language skills are bundled within songs using just a few rhymes (Futonge, 2005). In addition, utilizing songs in class environment entertains students, helps them feel relaxed and eliminates their bad attitudes towards a foreign language while learning a language structure through a song (Saricoban \& Metin, 2000).

There are certain aspects that need to be considered when using songs in EFL classes. Before choosing songs, the students' age, interests, language level, the grammar item to be studied and the language of the song's lyrics should be taken into account (Keskin, 2011). Information gap activities, finding synonyms and antonyms, learning vocabulary, creating discussion and clarifying doubts about abbreviations or slangs are some of many activities that could be developed when using songs (Perez, 2013).

Classroom activities through songs are perfect to develop students' creative talents and enrich their love of learning. According to Rusadze (2018) four classroom activities using songs as the main materials for teaching are: song dictation - improves students' listening abilities in learning to pronounce the contracted verb forms and helps students distinguish between long and short vowels; song reading - develops students' ability to understand the accurate meaning of the song and at the same time analyze the hidden message; split song - gives the students a chance to improve their comprehension ability by approaching a song in an interesting way; and word portraits - tries to stimulate students' imagination by creating a story based on the words taken from a song.

Research reveals that there are positive benefits on learning a foreign language through music and songs. First, music in the classroom can increase motivation. According to Kuśnierek (2016), popular songs influence the lives of students and relate to their different interests and daily experiences. Students easily learn the lyrics by heart and feel the effectiveness of their training, which in turn also increases their motivation for further learning. Second, music can decrease foreign language anxiety. Dolean \& Dolean (2014) and Dolean (2016) analyzed the impact of the use of songs in the foreign language and concluded by saying that teaching with songs reduced learner's anxiety level in foreign language classrooms. Third, using music can support attention. In the study of Wolfe \& Noguchi (2009), participants were more interested, concentrated and involved when listening to a musical story compared to a spoken story. Fourth, music and songs can provide cultural knowledge of the target language. Culturally great resources for language lessons could be the context, the singer, the music genre, etc. Last but not least, songs can contain rich linguistic information for example individual words, pronunciation or grammar. Medina (1990) reported that higher vocabulary scores were obtained from the participants who heard a sung 
story compared to the ones who heard a spoken story. Arevalo (2010) found that through songs students became familiar with native speakers' pronunciation as well as learned grammar unconsciously.

Meanwhile, some fewer positive concerns on using music and songs in English language teaching are: neighboring classes may be disturbed by loudly playing songs; some students become too excited and may disregard discipline so that control of the class may be lost easily; students do not have similar musical tastes (Murphey, 1992).

\section{Research objectives}

The major objectives of this study are:

- to analyze teachers' attitudes toward music use as a technique to help English language acquisition in primary schools;

- to examine whether teachers used music and songs in their lessons in the time of COVID-19 pandemic;

- to explore the possible pros and cons of using music in the English language teaching;

- to provide suggestions on teaching English through the use of songs.

\section{Research questions}

- This study investigates the following research questions:

- What are the Kosovo EFL teachers' views and attitudes on using songs in teaching EFL to YLs?

- Did EFL teachers have the opportunity to use music and songs in their lessons in the time of COVID-19 pandemic?

- What are the benefits and drawbacks of using songs in the English language classroom?

- What are the teachers' suggestions about teaching English through songs?

\section{Research Methodology}

The researcher focused on the qualitative method. According to Fraenkel \& Wallen (2009) qualitative research is particularly concerned with how things arise and mainly with the perspectives of the subjects of a study. In this qualitative study, data was collected through semistructured interviews with five primary school English teachers with an aim to survey their attitudes, perspectives, and thoughts towards using songs in their lessons as well as to investigate whether COVID-19 pandemic affected the use of songs in the English language classes. Therefore, we obtained more detailed qualitative information. The interview is composed of five statements and has been conducted in person/face to face. Participants were notified of the purpose of research and were requested to express their opinions on the given statements.

\section{Participants}

Five EFL teachers of different ages and from five primary schools in Kosovo took part in this research. The samples were selected purposefully in order to obtain the most capable data. 1 male teacher and 4 female EFL primary school teachers teaching different grade levels and working in different cities of Kosovo participated in this study. All the teachers got the master's degree 
and have attended trainings on teaching English through music and songs.

\section{Data Tools}

The type of data collection tool used in this research is a semi-structured interview which is a widely used method to obtain qualitative data. The researcher wanted to know and get the English teachers' views on the utilization of music and songs in teaching English as a foreign language to young learners in the context of Covid 19 pandemic. 5 English teachers were interviewed according to the interview instructions. The interview consists of 5 questions which can be seen in Appendix.

\section{Documentation}

To support the results of this research, different materials that proved the usage of songs in the English language classes were checked by the researcher. The teachers possessed and showed worksheets with the song's lyrics pertaining to the topic of the lesson; flashcards and story cards, that include words from different songs; posters that illustrate different objects and pictures related to the song's theme as well as teacher's book that provides instructions on how to teach a lesson using a specific song. Moreover, the researcher could see the radio, CDs, projector in the teachers' classrooms which are great tools to present music and songs to students.

\section{Data analysis}

Coding Data into Categories to analyze qualitative research, to identify the themes and to classify the data according to the code and themes was used in this research. Coding is a process through which different segments of data are identified that describe related phenomena and labeling these parts using the name of the board category (Lodico et al, 2005). In the coded data, the researcher identified the major and minor themes which helped the researcher to provide the results and offer a deeper and better understanding of the data. Moreover, this triangulation technique helped in finding the possible answers of the research questions. 


\section{Results}

Table 1. The content analysis of teachers' views on using music activities in the teaching of English in primary education

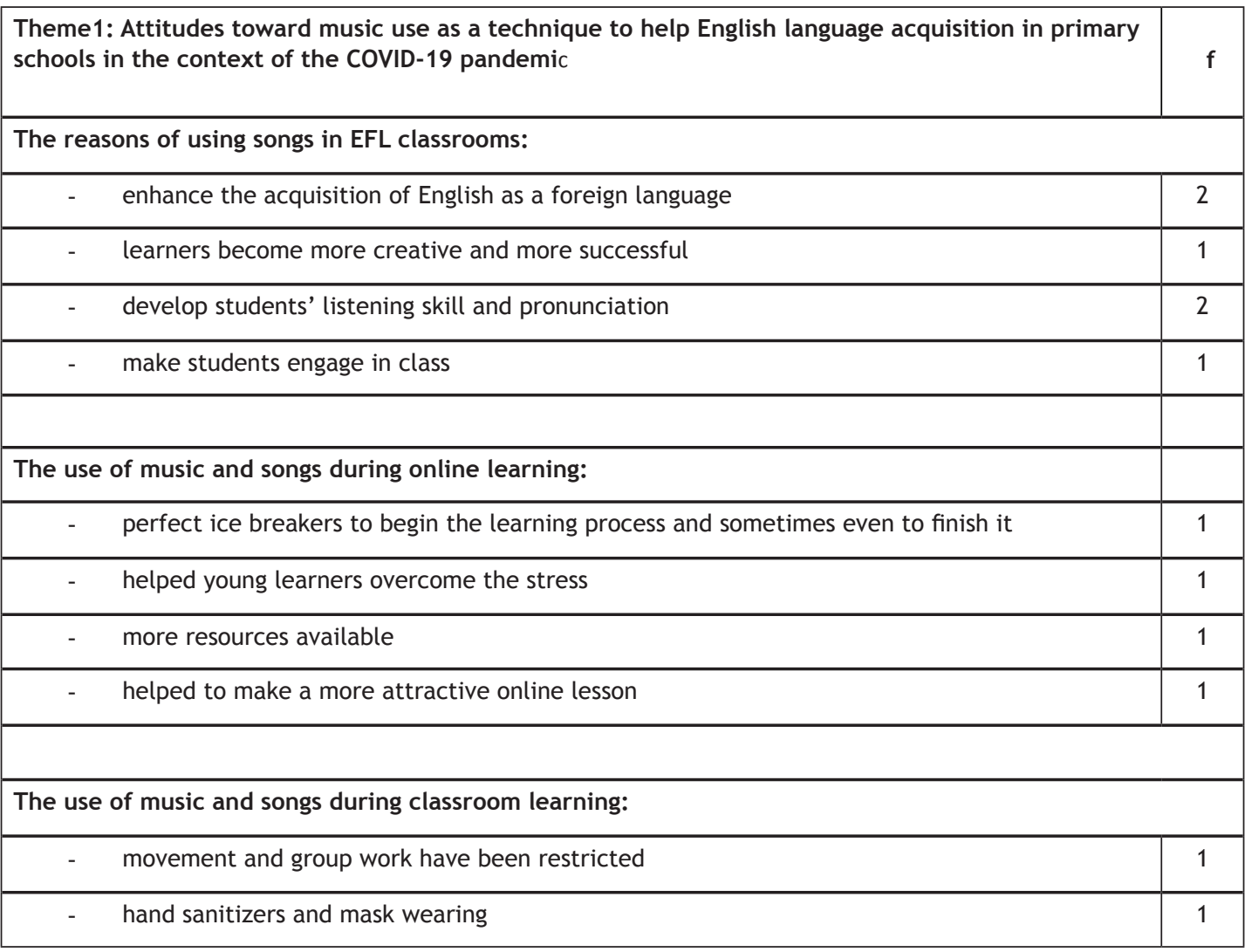

Some quotations on teachers' views and attitudes toward music use as a technique to help English language acquisition in primary schools in the context of the COVID-19 pandemic are as follows:

"We do incorporate music and songs in our classes a lot. They seem to attract our students to learn the lyrics which also enhance the acquisition of English as a foreign language" (T.1). "Music activities are a great tool to help learners understand and learn new things in another way. By listening to music and using some kind of their imagination through music, learners are more creative and more successful"
(T.2). "In my opinion, music activities in the teaching of English in primary education play an important role in developing students' listening skills and also help them pronounce new words correctly related to the lesson's topic" (T.3). "Music or songs in particular is/ are considered to be a great way of teaching, as students get engaged in the class trying to memorize the lyrics of a song taught by the teacher" (T.4). "While considering the context of the COVID-19 pandemic, music activities were more than welcomed by the learners, especially during online classes, they were perfect ice breakers to begin the learning process and sometimes even to finish it" (T.2). "Since Covid-19 pandemic 
has influenced people in general, songs used during online learning helped young learners overcome the stress caused by it" (T.5). "The pandemic made it easier for teachers to use more resources when teaching English online" (T.3). "When facing the pandemic, I may say that songs were a huge help to make a more attractive online lesson, especially for the young learners, because they get more enthusiastic and curious to know what will happen next" (T.2). "We have restricted the movement and group work which might have sought the touching of hands with one another" (T.1). "The students have to use hand sanitizers all the time and wear masks while singing songs. Kinesthetic learning style has still been there but with a lot of limitations due to the spread of the virus" (T.4)

Table 2. The content analysis of teachers' teaching techniques for using songs in their lessons

\begin{tabular}{|c|c|}
\hline Theme2: Teaching techniques for using songs in English lessons & f \\
\hline \multicolumn{2}{|l|}{ Teaching techniques: } \\
\hline - $\quad$ listen to the song & 4 \\
\hline - $\quad$ demonstrate some gestures & 2 \\
\hline - ' 'gap filling' songs & 1 \\
\hline - $\quad$ group competitions & 1 \\
\hline - $\quad$ flashcards & 2 \\
\hline \multicolumn{2}{|l|}{ Lesson topics: } \\
\hline - $\quad$ my body & 4 \\
\hline - $\quad$ fruits and vegetables & 2 \\
\hline - $\quad$ alphabet & 3 \\
\hline - $\quad$ numbers & 2 \\
\hline - colors & 2 \\
\hline - $\quad$ days of the week & 2 \\
\hline
\end{tabular}

Some quotations on teachers' teaching techniques for using songs in their lessons are as follows:

"They listen to the song and try to memorize or at least know how to pronounce the words. I usually ask the students demonstrate some gestures while playing the radio so that students memorize the song better. Sometimes, there are some 'gap filling' songs which students are supposed to fill after a verse of a song is heard. Other times, they compete in groups 'boys' versus 'girls' asking questions about the message of the song, or 'who will sing it better' assessing the way they pronounce the words and whether they got the concept of the overall song. They hold up flashcards making the connections of the language used on the song" (T.1). "They listen to the song then I ask learners to identify the new words and their meaning/message" (T.2). "The pupils listen to the song first and point to the various objects in the picture. The pupils listen, stand up, make gestures, and sing along. I usually put some flashcards, pertaining to the topic, on the board. Pupils have to point to the flashcard and 
say the corresponding word" (T.4). "My preferred technique is to give learners three or four words from the song and ask them to listen to the song and find the words that rhyme with them" (T.5). "Some topics we have covered using songs are related to: My room, My body, Fruits and Veggies, My house, Clothes, Animals, and so on" (T.1). "Some of the lesson topics are the alphabet, numbers, colors, body parts, different animals, fruits and vegetables, etc" (T.2). "I used songs for the lesson topics such as: body parts, the alphabet, numbers, months of the year, days of the week etc" (T.3). "I will mention 'Colors' 'State Verbs', 'Jobs', 'Happy birthday', 'Where's Alvin' and many more" (T.4). "I use music activities for the lesson topics such as: body parts, days of the week, grammar, alphabet and so on" (T.5).

Table 3. The content analysis of the materials that teachers used for teaching English through music

\begin{tabular}{|c|c|}
\hline Theme3: Materials used for teaching English through music & f \\
\hline$-\quad$ flashcards & 2 \\
\hline$-\quad$ posters & 2 \\
\hline$-\quad$ worksheets & 4 \\
\hline$-\quad$ YouTube videos & 3 \\
\hline
\end{tabular}

Some quotations on the materials that teachers used for teaching English through music are as follows:

"I have used story cards, flashcards, posters" (T.1). "I have used different materials, such as the radio, projector, CDs of the books and sometimes even worksheets" (T.2). ““I have used
YouTube video songs often with lyrics, some prepared materials with questions related to the song, worksheets etc" (T.3). "The school book, workbook, flashcards, posters, various printable worksheets from the Internet, YouTube videos and so on" (T.4). "YouTube videos and some worksheets." (T.5) 
Table 4. The content analysis of teachers' views on pros and cons of using music in the English language teaching

\begin{tabular}{|c|c|}
\hline $\begin{array}{l}\text { Theme4: The benefits and drawbacks of utilizing songs in the } \\
\text { language classroom }\end{array}$ & f \\
\hline Advantages: & 2 \\
\hline$-\quad$ maintain a good atmosphere in the classroom & 2 \\
\hline$-\quad$ provide a lot of fun & 1 \\
\hline$-\quad$ get learner's attention & 1 \\
\hline$-\quad$ learners get the proper pronunciation & 2 \\
\hline$-\quad$ increases students' motivation & 1 \\
\hline$-\quad$ learn new chunks of language & 1 \\
\hline$-\quad$ learn new vocabulary & 2 \\
\hline$\quad$ noise & 1 \\
\hline Disadvantages: & 1 \\
\hline$-\quad$ lnappropriate song & 1 \\
\hline$-\quad$ incorrect grammar rules, and slangs & \\
\hline
\end{tabular}

Some quotations on pros and cons of using music in the English language teaching are as follows:

"By using songs in English classes, the teacherbreakstheboredomandmaintains a good atmosphere in the classroom" (T.1). "Songs get learner's attention. learners have the chance to listen to a proper pronunciation" (T.2). "Songs provide a lot of fun to students in the classroom, create a positive atmosphere and also increase students' motivation" (T.3). "The advantages are that students get to learn new chunks of language, new vocabulary, have fun while learning English and get to share their talents and skills either in singing or in dancing" (T.4). "The advantages might be that by using songs in English lessons learners can acquire English easier and they can also end up motivated after listening to a song" (T.5). "One disadvantage would be the noise that might be created while playing songs" (T.1). "One of the disadvantages could be that the inappropriate song may not achieve the aimed objectives of the lesson. It needs to be appropriate for the topic, the age of the learners and their level of English, if it is not so, the lesson will be unsuccessful" (T.2). "A disadvantage could be that not all the students have the same preferred learning styles and learning English through songs somehow cannot be successful for each student in the classroom since this learning technique does not fit to every student's needs and learning styles" (T.3). "The only drawback would be having to manage the noise created within the classroom" (T.4). "The disadvantages might be that many lyrics do not follow correct grammar rules, and many of them contain slangs" (T.5). 
Table 5. The content analysis of teachers' suggestions on teaching English through the use of songs.

\begin{tabular}{|c|c|}
\hline $\begin{array}{l}\text { Theme 5: Suggestions put forward by the teachers as to teaching English through } \\
\text { songs }\end{array}$ & $\mathrm{f}$ \\
\hline$-\quad$ do not overuse songs & 1 \\
\hline$-\quad$ find suitable songs & 3 \\
\hline$-\quad$ conduct surveys & 1 \\
\hline$-\quad$ use songs with repetitive verses & 1 \\
\hline$-\quad$ analyze the song lyrics & 1 \\
\hline
\end{tabular}

Some quotations on teachers' suggestions on teaching English through the use of songs are as follows

"You have to take into account the students age and interests, try not to overuse songs" (T.1). "I think that the teacher must find songs that are appropriate for the student age and interests" (T.2). "I would suggest teachers to conduct surveys to find out student's favorite types of music. Try to use songs with repetitive verses which are easy to understand" (T.3). "“The teacher should pre listen the songs first to check whether they are relevant to what the teacher is aiming to teach" (T.4). "Teachers should analyze the lyrics from different points of view before implementing them" (T.5).

\section{Discussion}

This research sought the opinion of EFL teachers on using songs respectively music activities in teaching English as a foreign language to learners who attend primary school. The findings of the current study correspond with the research questions stated above. The main objective of the study was to examine the utilization of music and songs in EFL classes in the context of Covid 19 pandemic. The results of the present study provide us with the evidence that the pandemic made it easier for teachers to use more resources when teaching English online whereas when teaching English in the classroom, the precautions needed to be taken such as: physical distancing, hand sanitizers, mask wearing affected the use of music and songs in some way.

Based on the results from the interviews with teachers, songs and music are used as suitable teaching tools in primary education. They play an important role in developing students' listening skills and also help them pronounce new words correctly related to the lesson's topic. Moreover, music and songs can help young learners overcome the stress and at the same time can help them acquire and improve English. This result is consistent with the study of Engh, 2013a and Tse (2015) emphasizing that music can be beneficial for foreign language acquisition and for language skills. They also indicate that it lowers stress levels.

The employment of music and songs has numerous benefits in teaching and acquiring English as a foreign language. First, music can increase motivation (Kuśnierek, 2016); second, foreign language anxiety can be lowered through music (Dolean \& Dolean, 2014 and Dolean, 2016); third, music can sustain attention (Wolfe \& Noguchi, 2009). Similarly, from the results of this paper, it can be stated that music and songs 
provide a lot of fun to students in the classroom, create a positive atmosphere of learning and also increase students' motivation. Then, songs get learner's attention. Furthermore, music activities break the boredom and maintains a good atmosphere in the classroom.

Considering the disadvantages of using songs in the teaching of English, teachers of this research claimed that one disadvantage would be the noise that might be created while playing songs. Another disadvantage could be that not all the students have the same preferred learning styles and learning English through songs somehow cannot be successful for each student in the classroom since this learning technique does not fit to every student's needs and learning styles. As also stated in Murphey (1992), some fewer positive concerns on using music and songs in English language teaching are: some students become very excited and may disregard the discipline so that control of the class may be lost easily; students do not have similar musical taste etc.

\section{Conclusion}

Music is a great tool for expanding and understanding language because of the clear connection between songs and literacy. Songs have proved to be a great way of teaching and learning English. In particular, little students enjoy them a lot. Based on the qualitative data collected in this research, it can be concluded that songs can be valuable to primary school learners learning English if incorporated with clear teaching and learning intentions. The results show that incorporating music in English language classes enhances the acquisition of the foreign language. However, it is thought that certain aspects need to be taken into account when using songs in EFL classes such as: students' age and interests, their level of English, students' likes and dislikes, the lyrics of the songs and so on. Similarly, Keskin (2011) states that certain aspects should be taken into account before choosing songs such as: the age of the students, their interests, their language level, the grammar point to be studied and the language of the songs.

However, the pandemic has given another flow of all the way EFL teachers conduct activities with young learners. The Covid 19 pandemic has affected the utilization of songs in the English language classes during in-person learning. It has specifically affected some activities which match to the kinesthetic learning style in which learning takes place as learners engage a physical activity. Teachers have restricted the movement and group work to prevent the spread of the virus as well as to ensure that learners continue their education in a safe and healthy environment. So, whenever music activities are used in the English language classroom, learners either learn the song, highlight the key words aimed to achieve for a specific lesson, sing them individually or as a choir or they point to the flashcards put by the teacher on the board and say the corresponding word, listen and repeat the words individually or chorally, stand up, make gestures, and sing along.

It is suggested that teachers should continue using music and songs when teaching English because they are effective techniques that can enhance language skills and at the same time create fun in class. 


\section{Biodata of Author}

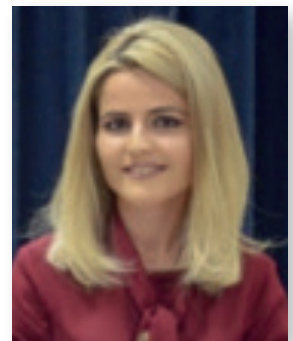

Assist. Prof. Dr. Teuta Agaj Avdiu

She has received a bachelor degree in English Language and Literature from the AAB College in Prishtina, Kosovo (2009), a master degree in English language teaching from the South East European University in Tetovo, North Macedonia (2013) and a $\mathrm{PhD}$ degree in English language and literature from the South East European University in Tetovo (2018). She works as a full-time professor for English language courses at the Public University "Kadri Zeka" in Gjilan, Kosovo since 2019, before that she worked as a full-time assistant for five years. From 2016 to 2021 she taught 'English Syntax I', 'English Syntax II', 'English Morphology', 'The History of the English Language', 'The Structure of Modern English' and 'First and Second Language Acquisition' at the public University "Ukshin Hoti” Prizren, Kosovo. From 2012 to 2016 she taught 'English Syntax I' and 'English Syntax II' at the AAB college in Prishtina. From 2009 to 2014 she taught English in public primary and secondary schools as well as in private English Language schools. She published several scientific articles in scientific journals and also participated in several national and international conferences. Affilation: Public University "Kadri Zeka “, Gjilan, Kosovo. ORCID ID: 0000-00031992-5946 e-Mail: teuta.agaj@uni-gjilan.net 


\section{References}

Arévalo, E. (2010). The use of songs as a tool to work on listening and culture in EFL classes.

Cameron, L. (2001). Teaching languages to young learners. Cambridge: Cambridge University Press.

Cuadernos de Lingüística Hispánica, 15, 121-138. https://www.redalyc.org/ pdf/3222/322227521008.pdf

Dolean, D. D. (2016). The effects of teaching songs during foreign language classes on students' foreign language anxiety. Language Teaching Research, 20(5), 638-653. https://doi. org/10.1177/1362168815606151

Dolean, D. D., \& Dolean, I. (2014). The Impact of Teaching Songs on Foreign Language Classroom Anxiety. Philologica Jassyensia, 10, 513-518.

Edden, J. (1998). Language and Music in Bearne, Eve. (Ed.) Use of Language Across the Primary Curriculum. Florence, KY, USA: Routledge.

Engh, D. (2013a). Effective use of music in language-learning: A needs analysis. Humanising Language Teaching, 15(5), 1-9. https://www.academia. edu/8652569/Effective_Use_of_Music in_Language_Learning_A_Needs_ Analysis?auto=download

Fraenkel, J. R. \& Wallen, E. N. (2009). How to Design and Evaluate Research in Education: Seventh Edition. New York: McGraw-Hill.

Futonge, K. (2005). Using English Videos and Music in EFL, ESL Classrooms. ESL Magazine: Read \& Publish ESL articles. Johnstone, R. (2002). Addressing 'the age factor': Some implications for languages policy. Strasburg, France: Council of Europe.

h t t p : / / c digital.uv.mx / bitstream/123456789/34271/1/ munozperezingrid.pdf

http://lib.unnes.ac.id/1064/1/1980.pdf

Illinois at Urbana-Champaign. Retrieved from http://writingthetrueself.com/ pdfs/Jon_Stansell_The_Use_of_Music_ for_Learning_Languages.pdf

Keskin, F. (2011). Using songs as audio materials in teaching Turkish as a foreign language.

Kuśnierek, A. (2016). The role of music and songs in teaching English vocabulary to students. World Scientific News, 43(1),43-48. http://www. worldscientificnews.com/wp-content/ uploads/2015/10/WSN-431-2016-1-55. pdf

level. (Master's thesis, Universidad Veracruzana, Veracruz, Mexico). Retrieved from

Lo, R. \& Li, H.C. (1998). Songs enhance learner involvement. English Teaching Forum, 36(3), 8-11.

Lodico, Marguerite G., Spaulding, Dean T \& Voegtle, Katherine H. (2005). Methods in Educational Research. US: A willey Imprint.

Maess, B. \& Koelsch. S. Gunter, C. Th. 
Friederici, D. A. (2001). Musical Syntax is processed in Broca's Area: An MEG study. Nature Nevroscience, 4(5), 540-545. DOI https: / / doi.org/10.1038/87502

McDermott, J. \& Hauser, D. M. (2005). The origins of music: Innateness, uniqueness, and evolution. Music Perception, 23(1), 29-59. https://doi. org/10.1525/mp.2005.23.1.29

Medina, S. L. (1990). The Effects of Music upon Second Language Vocabulary Acquisition. Paper presented at the Annual Meeting of the Teachers of English to Speakers of Other Languages conference, US: San Francisco. https: // files.eric.ed.gov/fulltext/ED352834.pdf

Murphey, T. (1992). Music and song. Oxford: Oxford University Press.

Pearl, G. (1995). Janacek's Moravian folk songs: A prosodic analysis. U-Web Students Web Service. http://www. uweb.ucsb.edu/ jpearl/Janacek.html

Pérez, M. (2013). Songs as a tool to develop listening and speaking skills at a beginners'

Ratnasari, H. (2007). Songs to improve the students' achievement in pronunciation English

Rusadze, I. (2018). Songs Enhance Students Involvement. Conference: 5th International Research Conference (IRCELT). Kutaisi, Georgia. https: / / www.researchgate.net / publication/326262723_Songs_Enhance_ Students_Involvement

Saricoban, A. \& Metin, E. (2000). Songs, verse and games for teaching grammar. The Internet TESL Journal, 6(10), http: / / iteslj.org/Techniques/Saricoban-Songs. html

Stansell, J. (2005). The use of music for learning language: A review. University of

Tse, A. Y. (2015). Malaysian teachers' perspectives on using songs in English language teaching. International Journal of Social Science and Humanity, 5(1), 87-89. http://www.ijssh.org/ papers/428-H10021.pdf

Turkish Online Journal of Educational Technology, 10(4), 378-383. https:// files.eric.ed.gov/fulltext/EJ946647.pdf

Wolfe, D. E., \& Noguchi, L. K. (2009). The use of music with young children to improve sustained attention during a vigilance task in the presence of auditory distractions. Journal of Music Therapy, 46(1), 69-82. https://doi.org/10.1093/ jmt/46.1.69

words (Master's thesis, Semarang State University, Semarang, Indonesia). Retrieved from 


\section{Appendix 1- Teachers' Interview Questions}

Q1. What do you think of music activities in the teaching of English in primary education? Please explain your view in the context of the COVID-19 pandemic. Did the pandemic affect the utilization of songs in the English language classes?

Q2. Please explain in detail your teaching techniques for using songs in your lessons.

Q3. What materials did you use for teaching English through music?

Q4. Are there any advantages or disadvantages of using songs in the teaching of English?

Q5. Please provide your suggestions on teaching English through the use of songs. 
